\title{
Research on Supplier Selection of Home Appliance Industry Supply Chain Based On Entropy Weight and TOPSIS Method
}

\author{
Yanmeng Zhang ${ }^{1}$, Shengshi Zhou ${ }^{2}$, Di Wu ${ }^{3}$ \\ ${ }^{1,2,3}$ School of Qingdao Technological University, Qingdao 266520, China. \\ a)1832704768@qq.com
}

Keywords: Supplier selection, Home appliance industry, Supply chain, TOPSIS

\begin{abstract}
As the starting point of the supply chain and the end point of the loop feedback, the behavior of the supply chain suppliers in the home appliance industry is important. The evaluation index system is established on the basis of product quality, delivery reliability and technical ability. Using entropy weight method and TOPSIS make an objective and comprehensive evaluation of suppliers to select suitable suppliers for downstream enterprises. At the same time, the feasibility and effectiveness of the evaluation index system is proved by the example analysis, which provides a reference for solving practical problems.
\end{abstract}

\section{INTRODUCTION}

Although China's home appliance industry has gone through differentiation, reorganization and a series of joint integration and each manufacturer has formed a full competition in terms of product, price and promotion, but it also encountered some difficulties and setbacks in the development process, such as the homogenization of products, raw material prices, energy shortage, the price war, customer service absence. Effective supplier selection process is very important for successful manufacturing organizations. Selection of suitable suppliers will be directly related to the supply chain cost reduction, response speed and efficiency. In other words, excellent suppliers are significant for improving the quality of products and services, and rapid and low price to meet customer needs, thereby enhancing the overall competitiveness of the supply chain [1].

\section{OVERVIEW OF SUPPLY CHAIN SUPPLIER IN HOME APPLIANCE INDUSTRY}

\section{Supplier Meaning In Supply Chain Environment}

The supply chain is composed of raw materials and parts suppliers, manufacturers, distributors and retailers, which is designed to deliver the products to customers in the agreed time. The members in the supply chain are called the nodes of the supply chain, and the upstream nodes are the suppliers of the downstream nodes [2].Suppliers can be farmers, production bases, manufacturers, agents, wholesalers, importers, etc.Meantime, it is necessary to avoid too many intermediate links suppliers.

\section{Classification Of Suppliers}

Suppliers can be divided into strategic suppliers, preferred suppliers, provisional suppliers, exit passive, exit active and identity pending suppliers. The features are as follows: strategic suppliers refer to those supplier who are beneficial to companies. They provide complex technology and long production cycle products. They may be the only supplier.Preferred suppliers provide products or services which can be get in other suppliers, but companies tend to use preferred suppliers. This is the fundamental difference with strategic suppliers. Generally speaking, it is the first time for provisional suppliers to provide products or services to the company, and its performance is not well understood. So,there is a year to investigate. Exit passive suppliers should not get new products, but the company is not actively moving the existing business. With the completion of the main product life cycle, the vendor will naturally be out. Exit active suppliers not only can't get the new business, but also have to be moved away the existing business. 


\section{ESTABLISHMENT OF SUPPLIER EVALUATION INDEX SYSTEM FOR HOME APPLIANCE INDUSTRY}

\section{Thoughts On The Construction Of Supply Chain Supplier Evaluation Index In Home Appliance Industry}

Supplier selection as the first step in the efficient operation of the supply chain of the household appliance industry occupies a pivotal position. Therefore, for the supplier selection evaluation index system construction, we should establish a comprehensive, objective and fair evaluation index system on the basis of systematic, dynamic, concise scientific, comparable, operational, quantifiable, comprehensive principles .Based on the view of downstream node enterprises, starting from the angle of service level and development potentiality, modern information, there are six indicators can be selected as follows :product cost, product quality, delivery reliability, network coverage, technical ability, financial level [3]. Among them, the product cost is the loss index, and the other five indicators are the profitability index. As shown in table 1:

TABLE 1. Supplier Evaluation Index of Home Appliance Industry.

\begin{tabular}{|c|c|c|}
\hline Index & Measure way & Explain \\
\hline $\begin{array}{c}\text { Product } \\
\text { cost }\end{array}$ & $\begin{array}{l}\text { raw material costs, management costs, } \\
\text { information costs, circulation costs, } \\
\text { inventory costs, etc. }\end{array}$ & $\begin{array}{l}\text { It is related to the quality of products } \\
\text { and the supply chain is whether } \\
\text { operate smoothly. }\end{array}$ \\
\hline $\begin{array}{l}\text { Product } \\
\text { quality }\end{array}$ & $\begin{array}{l}\text { quality pass rate, durability, material, } \\
\text { performance, production process, and } \\
\text { similar products, etc. }\end{array}$ & $\begin{array}{l}\text { The quality of the parts or finished } \\
\text { products directly determines the } \\
\text { market competitiveness and } \\
\text { elimination of the finished product. }\end{array}$ \\
\hline $\begin{array}{l}\text { Delivery } \\
\text { reliability }\end{array}$ & $\begin{array}{l}\text { delivery on time, product quality, } \\
\text { delivery lead time, logistics status, } \\
\text { timely response, etc. }\end{array}$ & $\begin{array}{l}\text { It is related to the inventory, market } \\
\text { response speed and corporate } \\
\text { reputation of supply chain node } \\
\text { enterprises. }\end{array}$ \\
\hline Network coverage & $\begin{array}{l}\text { logistics tracking ability, information } \\
\text { network construction, computer } \\
\text { hardware configuration, information } \\
\text { system security, etc. }\end{array}$ & $\begin{array}{l}\text { It is good for transmitting } \\
\text { information, tracking cargo location } \\
\text { and status and collecting technical } \\
\text { information. }\end{array}$ \\
\hline $\begin{array}{c}\text { Technical } \\
\text { ability }\end{array}$ & $\begin{array}{l}\text { technical parameters, technical } \\
\text { personnel proportion, innovation } \\
\text { ability, New product cycle rate, R \& D } \\
\text { capability, R \& D rate, etc. }\end{array}$ & $\begin{array}{l}\text { It can shorten the time of } \\
\text { technological innovation, promote } \\
\text { industrial innovation, reduce waste } \\
\text { of time and resources. }\end{array}$ \\
\hline $\begin{array}{c}\text { Financial } \\
\text { level }\end{array}$ & $\begin{array}{l}\text { the amount of assets, staff salaries, } \\
\text { scientific and technological } \\
\text { achievements, facilities investment, } \\
\text { etc. }\end{array}$ & $\begin{array}{l}\text { It can help companies to determine } \\
\text { whether the supplier development is } \\
\text { stable and whether the supplier has } \\
\text { market potential. }\end{array}$ \\
\hline
\end{tabular}

\section{Determination Of Index Weight By Entropy Weight Method}

Entropy [4] was originally a thermodynamic concept, first introduced by C.E.Shannon in information theory, known as information entropy. The information entropy is a concept that is independent of thermodynamic entropy and it is a kind of objective weighting method. Compared with the AHP, expert scoring method, fuzzy comprehensive evaluation method, the entropy weight method is more accurate and objective, which can better explain the results. In the use process, according to the degree of variation of each index, the entropy weight method calculates the entropy weight of each index by using the information entropy, and then modifies weight of each index by entropy weight. We can get objective weights finally. If the entropy of index is smaller, indicating the degree of variation of index value is larger. At the same time, it can provide more information, and in the comprehensive evaluation, the effect of this index is bigger.Naturally, its weight should 
be bigger. On the contrary, if the entropy of index is greater, the weight should be smaller.

1)Standardized treatment of index values

According to the established index system, the initial data matrix is established:

$$
R=\left[\begin{array}{cccc}
r_{11} & r_{12} & \cdots & r_{1 n} \\
r_{21} & r_{22} & \cdots & r_{2 n} \\
\vdots & \vdots & \vdots & \vdots \\
r_{m 1} & r_{m 2} & \cdots & r_{m 3}
\end{array}\right]
$$

Among them, $r_{i j}$ represents the evaluation value of the first $i(i=1,2, \ldots, m)$ supplier under the first $j(j=1,2, \ldots, n)$ index.

The initial data matrix is normalized to get the matrix $\mathrm{P}=\left\{p_{i j}\right\}_{m \times n}$,

(1)

$$
p_{i j}=\frac{r_{i j}}{\sum_{i=1}^{m} r_{i j}}(i=1,2, \ldots, m ; j=1,2, \ldots, n)
$$

2)Calculate index weight by entropy weight method

There are $\mathrm{m}$ items to be evaluated and $\mathrm{n}$ evaluation indicators, and formed the original evaluation matrix $R=\left(r_{i j}\right)_{m \times n}$, for a certain index $r_{j}$ having information entropy:

$$
e_{j}=-k \sum_{i=1}^{m} p_{i j} \cdot \ln p_{i j}, k=\frac{1}{\ln m}, 0 \leq e j \leq 1
$$

Calculate the weight of the first $\mathrm{j}$ index $\mathrm{w}_{\mathrm{j}}$ :

$$
w j=(1-e j) / \sum_{j=1}^{n}(1-e j)^{j=1,2, \ldots, n}
$$

\section{SUPPLIER SELECTION OF HOME APPLIANCE INDUSTRY BASED ON TOPSIS METHOD}

\section{TOPSIS Method Introduction}

The TOPSIS[5] method is based on the degree of closeness between a limited number of evaluation objects and the ideal goal, and evaluate the relative advantages and disadvantages in the existing objects. TOPSIS is a ranking method,which is approximate to the ideal solution, and its basic principle is to sort out the distance between the evaluation object and the optimal solution, the worst solution. "Ideal solution" and "negative ideal solution" are two basic concepts of the TOPSIS method. The ideal solution is an optimal solution of the plan and all of its properties have reached the best value; and the negative ideal solution is the worst scenario , and all of its properties have reached the worst value . Ranking rule is to compare the alternatives with the ideal solution and the negative ideal solution. If there is a solution that is closest to the ideal solution and at the same time is away from the negative ideal solution, the solution is the best plan, otherwise it is not the best.

\section{The Calculation Process Of TOPSIS Method}

1)Calculate the weighted matrix, and construct the ideal value vector $\mathrm{X}^{+}$and negative ideal vector $\mathrm{X}^{-}$

Normalized matrix $P=\left\{p_{i j}\right\}_{m \times n}$ can be weighted norm and get matrix $X=\left\{x_{i j}\right\}_{m \times n}$

$$
x_{i j}=w_{j} \times p_{i j}(i=1,2, \ldots, m ; j=1,2, \ldots, n)
$$

$X^{+}=\left(X_{1}^{+}, X_{2}^{+}, \ldots, X_{n}^{+}\right)=\left\{\max _{i} x_{i j}\left|j \in J_{1: \min } x_{i j}\right| j \in J_{2}\right\} X^{-}=\left(X_{1}^{-}, X_{2}^{-}, \ldots, X_{n}^{-}\right)=\left\{\min _{i} x_{i j} \mid j \in J_{\left.1: \max _{i} x_{i j} \mid j \in J_{2}\right\}}\right.$

Among them, $\mathrm{J} 1$ is a collection of revenue indicators, $\mathrm{J} 2$ is a collection of loss indicators . 
2)Calculate the distance between the evaluation values of each scheme and $X^{+}, X^{-}$respectively, and obtain the closeness between the evaluation value vector and $\mathrm{X}^{+}, \mathrm{X}^{-}$.

$$
D_{i}^{+}=\sqrt{\sum_{j=1}^{n}\left(X_{i j}-X_{j}^{+}\right)^{2}}, D_{i}^{-}=\sqrt{\sum_{j=1}^{n}\left(X i j-X_{j}^{-}\right)^{2}}
$$

(6)

$$
C i=\frac{D_{i}^{-}}{D_{i}^{+}+D_{i}^{-}}(i=1,2, \ldots, m)
$$

3)Select the best supplier

The largest $\mathrm{C}_{\mathrm{i}}$ is the best solution, $\mathrm{C}_{\mathrm{i}}=\max \left(\mathrm{C}_{1}, \mathrm{C}_{2}, \ldots, \mathrm{C}_{\mathrm{m}}\right)$

\section{CASE ANALYSIS}

A household appliance manufacturing enterprises needs to purchase a number of new parts as raw materials of TV production. The existing 5 suppliers can provide the parts. In order to ensure the quality of the machine, we conduct a comprehensive assessment for the suppliers, and choose the best suppliers for cooperation. Evaluation index system, as the above mentioned, the supplier evaluation index value can be got by the expert scoring method and business data, as shown in table 2:

TABLE 2. Five Suppliers Evaluation Index Data.

\begin{tabular}{c|c|c|c|c|c|c}
\hline $\begin{array}{c}\text { Parts } \\
\text { supplier }\end{array}$ & $\begin{array}{c}\text { Product cost } \\
\text { (yuan) }\end{array}$ & $\begin{array}{c}\text { Product } \\
\text { quality }\end{array}$ & $\begin{array}{c}\text { Delivery } \\
\text { reliability }\end{array}$ & $\begin{array}{c}\text { Network } \\
\text { coverage }\end{array}$ & $\begin{array}{c}\text { Technical } \\
\text { ability }\end{array}$ & $\begin{array}{c}\text { Financial } \\
\text { level }\end{array}$ \\
\hline A & 10 & 0.89 & 0.91 & 0.77 & 0.94 & 0.72 \\
\hline B & 8 & 0.94 & 0.89 & 0.74 & 0.96 & 0.57 \\
\hline C & 9 & 0.92 & 0.92 & 0.68 & 0.95 & 0.67 \\
\hline D & 8 & 0.88 & 0.85 & 0.71 & 0.92 & 0.50 \\
\hline E & 10 & 0.87 & 0.95 & 0.78 & 0.93 & 0.56 \\
\hline
\end{tabular}

Table 2 is normalized to get matrix P:

$$
P=\left[\begin{array}{llllll}
0.2222 & 0.1978 & 0.2013 & 0.2092 & 0.2000 & 0.2384 \\
0.1778 & 0.2089 & 0.1969 & 0.2011 & 0.2043 & 0.1887 \\
0.2000 & 0.2044 & 0.2035 & 0.1848 & 0.2021 & 0.2219 \\
0.1778 & 0.1956 & 0.1881 & 0.1929 & 0.1957 & 0.1656 \\
0.2222 & 0.1933 & 0.2102 & 0.2120 & 0.1979 & 0.1854
\end{array}\right]
$$

The weight of each index can be obtained by using the entropy weight method:

$$
\mathrm{W}=(0.3069,0.0297,0.0396,0.0792,0.0099,0.5347)
$$

The weighted matrix $\mathrm{X}$ can be obtained, as shown in table 3:

TABLE 3. Weighted Data Matrix.

\begin{tabular}{c|c|c|c|c|c|c}
\hline $\begin{array}{c}\text { Parts } \\
\text { supplier }\end{array}$ & $\begin{array}{c}\text { Product cost } \\
\text { (yuan })\end{array}$ & $\begin{array}{c}\text { Product } \\
\text { quality }\end{array}$ & $\begin{array}{c}\text { Delivery } \\
\text { reliability }\end{array}$ & $\begin{array}{c}\text { Network } \\
\text { coverage }\end{array}$ & $\begin{array}{c}\text { Technical } \\
\text { ability }\end{array}$ & $\begin{array}{c}\text { Financial } \\
\text { level }\end{array}$ \\
\hline A & 0.06819 & 0.00587 & 0.00797 & 0.01657 & 0.00198 & 0.12747 \\
\hline B & 0.05457 & 0.00620 & 0.00780 & 0.01593 & 0.00202 & 0.10090 \\
\hline C & 0.06138 & 0.00607 & 0.00806 & 0.01464 & 0.00200 & 0.11865 \\
\hline D & 0.05457 & 0.00581 & 0.00745 & 0.01528 & 0.00194 & 0.08855 \\
\hline E & 0.06819 & 0.00574 & 0.00832 & 0.01679 & 0.00196 & 0.09913 \\
\hline
\end{tabular}

$\mathrm{X}^{+}=(0.05457,0.00620,0.00832,0.01679,0.00202,0.12747)$

$\mathrm{X}^{-}=(0.06819,0.00574,0.00745,0.01464,0.00194,0.08855)$

Calculate the distance between the evaluation values of each scheme and $\mathrm{X}^{+}, \mathrm{X}^{-}$respectively, and obtain the closeness between the evaluation value vector and $\mathrm{X}^{+}, \mathrm{X}^{-}$, as shown in table 4 : 
TABLE 4. $\mathrm{Di}^{+} 、 \mathrm{Di}^{-}$、 and $\mathrm{C}_{\mathrm{i}}$ Calculation Results

\begin{tabular}{c|c|c|c}
\hline Supplier & $\mathbf{D}_{\mathbf{i}}^{+}$ & $\mathbf{D}_{\mathbf{i}}^{-}$ & $\mathbf{C}_{\mathbf{i}}$ \\
\hline $\mathrm{A}$ & 0.01346 & 0.03897 & 0.74328 \\
\hline $\mathrm{B}$ & 0.02659 & 0.01831 & 0.40780 \\
\hline $\mathrm{C}$ & 0.01125 & 0.03087 & 0.73291 \\
\hline $\mathrm{D}$ & 0.03896 & 0.01364 & 0.25932 \\
\hline $\mathrm{E}$ & 0.03138 & 0.01083 & 0.25657 \\
\hline
\end{tabular}

According to the principle of TOPSIS method, the larger the $\mathrm{C}_{\mathrm{i}}$ value is, the closer to the optimal solution. Therefore, the evaluation results of 5 suppliers are classified as $\mathrm{A} \succ \mathrm{C} \succ \mathrm{B} \succ \mathrm{D} \succ \mathrm{E}$.So, $\mathrm{A}$ is the best choice.

\section{CONCLUSION}

In order to maintain the normal production and operation, each node in the supply chain of the household electrical appliance industry must have qualified suppliers to provide various parts. However,many companies only look for suppliers when there is a lack of supply. As a result, it is often impossible to find suitable suppliers, wasting time and money. Based on the three aspects of the service level, the development potential and the information modernization, the paper sets up an index system to evaluate the suppliers, which makes the evaluation more comprehensive and objective. The entropy weight method is used to determine the weight of index, which can avoid the subjectivity of weight. Using TOPSIS method to evaluate the suppliers and making the original data standardization can eliminate the influence of different index dimension and reflect the gap of the scheme objectively. Simultaneously, it can reflect the actual situation and has the advantages of reality, intuition and reliability. On the one hand, supplier evaluation index system established by this paper can evaluate the suppliers and provide reference for the choice of the enterprise. On the other hand, it can promote the suppliers to improve their comprehensive ability, technical level, corporate reputation, and make a contribution for the development of home appliance industry supply chain.

\section{REFERENCES}

[1]. Shuliang Zhang, Youling Chen, Dou Zhang,Supplier selection decision method in supply chain, J. computer application research, (2015).

[2]. Xiaofeng Shao, Jianhua Ji , Peiqing Huang,Study on the method of supplier selection in the supply chain: quantitative economics and technology, J. quantitative economics and technology research, (2001),pp.80-83

[3]. Lin Ca,.Research on the evaluation system of the third party reverse logistics provider in the home appliance industry , J. logistics science and technology, (2015),pp.103-106

[4].Jun Wen ,Research on performance evaluation of airlines based on entropy weight, J. science technology and engineering, (2009).

[5]. Qing Wang, Shengshi,Zhou, Qingjun.Fang., Research on supply chain finance logistics enterprise selection based on entropy weight and TPOSIS method, J. supply chain management.(2015).

[6]. Yanghua Ou. Supplier selection management in supply chain, J. science and technology information, (2012) 